\title{
Meat Fatty Acid and Cholesterol Content of Native Indonesian Muscovy Duck Fed with Rice Bran in Traditional Farm
}

\author{
Dwi Margi Suci, Zurrahmi Fitria, Ratu Mutia \\ Department of Nutrition and Feed Technology, Faculty of Animal Science, Bogor Agricultural University \\ Corresponding author email: dwi.margi2@gmail.com
}

\begin{abstract}
Fat, cholesterol and fatty acid profile of breast and thigh meat of 12 Muscovy ducks ( 6 drakes) aged 8 weeks from the local farm in Bogor, West Java were analyzed in thus study. In general, Muscovy ducks were fed with rice bran twice a day and free-ranged in the backyard. The nutrition of rice bran is varied in crude protein, crude fiber, fat, and ash content. Muscovy ducks were slaughtered and the percentage of carcass weight, fat, cholesterol and fatty acid profile of the breast and thigh meat were measured and analyzed. The

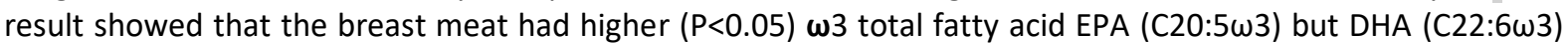
and linolenic acid ( $\mathrm{C} 18: 3 \omega 3)$ were not significant compared to that of thigh meat. Concentration of linolenic acid in breast meat ranged from 0.26 to $0.51 \%$ of fat and 0.35 to $0.39 \%$ of fat in thigh meat. Linoleic acid (C18:2w6) in breast and thigh meat was $7.64-10.73 \%$ and $5.17-13.93 \%$ fat, respectively. DHA concentration ranged from $0.13-1.31 \%$ fat in breast meat and EPA in thigh meat was approximately $0.08-0.32 \%$ fat. EPA was significantly higher $(\mathrm{P}<0.05)$ in breast meat $(0.03-0.28 \%)$ than thigh meat $(0.05-0.08 \%)$ The study produced $\omega$ 6:3 ratio ranged 6.50-24.14 and 8.94-31.64 in breast and thigh meat, respectively.
\end{abstract}

Key words: Muscovy duck, fatty acid, fat, cholesterol.

Abstrak. Penelitian ini bertujuan untuk mendapatkan informasi tentang kandungan leamk,cholesterol dan profil asam lemak dari daging dada dan daging paha entok (Muscovy duck) yang dipelihara secara tradisional oleh masyarakat. Entok diberi pakan dedak padi yang mempunyai kualitas rendah dan beragam dari 6 peternak yang ada di kota Bogor, Jawa Barat, Indonesia. Dedak padi diberikan dua kali sehari yaitu pagi dan siang kemudian entok di lepas disekitar halaman rumah. Penelitian ini menggunakan 12 sampel entok berumur 8 minggu kemudian dipotong dan diukur karkas, persentase daging dada dan paha dan kandungan lemak,cholesterol dan asam lemak. Hasil penelitian diperoleh daging dada lebih tinggi kandungan total asam lemak $\omega 3(\mathrm{P}<0.05)$, EPA $(\mathrm{C} 20: 5 \omega 3)(\mathrm{P}<0.05)$ daripada daging paha tetapi DHA $(\mathrm{C} 22: 6 \omega 3)$ tidak berbeda nyata. Kadar asam linolenat (C18: $3 \omega 3$ ) pada daging dada berkisar dari 0,26 to $0,51 \%$ total lemak dan 0,35 to $0,39 \%$ total lemak di daging paha. Asam linoleat (C18:2 $\omega$ 6) berkisar 7,64-10,73\% total lemak di daging dada dan $5,17-13,93 \%$ total lemak di daging paha. Kadar DHA (C22:6w 3) berkisar 0,13-1,31\% total lemak di daging dada dan EPA berkisar $0,08-0,32 \%$ total lemak di daging paha. Kadar EPA lebih tinggi $(P<0,05)$ di daging dada dibandingkan daging paha berkisar $0,03-0,28 \%$ total lemak (daging dada) sampai 0,05-0,08 \% total lemak (daging paha). Penelitian ini menghasilkan rasio $\omega 6 / \omega 3$ berkisar 6,50-24,14 di daging dada dan 8,94-31,64 di daging paha.

Kata kunci: entok, Muscovy duck, asam lemak, cholesterol

\section{Introduction}

Muscovy duck is one of common poultry that are commonly few in the rural communities together with other poultry such as chicken and duck. Muscovy ducks are generally still maintained traditionally generally fed with rice bran and sometimes mixture with rice from household waste. The purposes of raising Muscovy duck by the rural communities are to become an alternative food source and as a parent for incubating duck eggs. Muscovy duck livestock development has a great opportunity to become the source of meat. However, the consumers now have more attention to the nutritional composition of meat, such as fat, cholesterol and fatty acid profile.

One reason Muscovy duck meat demand is very slow to increase is the opinion that Muscovy duck meat has high content of fat and cholesterol which can lead to increased risk of coronary heart disease (Hu et al., 2001; Krauss et al., 2000). Siri-Tarino et al. (2015) reported that the effect of SFAs on cardiovascular 
disease (CVD) risk are modulated by the nutrients that replace them and their food matrices. Therefore the information of fatty acids, cholesterol and fatty acid profile content is required. The content of fat, cholesterol and fatty acid profile can be controlled via the feed source of oil content in the animal feed (Schivone et al., 2010; Wood, et al., 2003, Krejci-treu et al.2010), feed ingredients with high source of omega 3 microalga (Schiavone et al., 2007), differences in eating habits (Krimpen et al., 2011), and the influence of protein (Ahmet et al., 1997). Furthermore, genetics also affects the nutrient content of the Muscovy duck meat (Baeza, 2006, Woloszyn, 2006). The objective of the study is to obtain information on the quality of Muscovy duck meat that was traditionally maintained

\section{Materials and Methods}

The Muscovy duck meat obtained from 12 ducks consisted of six males and six females were from six local farm located in Taman Sari Sub-district, Nanggung Sub-district, Cijeruk Subdistrict, Cigombong Sub-district, Tenjolaya Subdistrict,and Pamijahan Sub-district, Bogor City, West Java, Indonesia. Two Muscovy duck samples were taken from each local farm. Male Muscovy ducks aged 8 weeks had a body weight of 913-1,085 grams and female Muscovy ducks around 836-994 grams. Muscovy ducks are slaughtered to obtain samples of breast meat and thigh meat in order to analyze the content of fat, cholesterol and fatty acids.

Six samples of rice bran samples from local farm were analyzed proximate using the AOAC 2005 method. Breast and thigh meat were analyzed the moisture, fat, cholesterol and fatty acid using AOAC 2002. The read used HPLC to cholesterol analyzed and GC to fatty acid analyzed.

In this research, the content of SFA, MUFA, PUFA, $\omega 6$, and $\omega 3$ and the ratio of $\omega 6$, and $\omega 3$ are calculated from the fatty acid composition in breast and thigh meat.

The research data were analyzed using $\mathrm{T}$ test to get the real difference between the average treatments. The variables measured: (1) Live weight, carcass weight, also the weight and percentage of breast meat and thigh meat, and (2) The content of fat, cholesterol, and fatty acid profile of breast meat and thigh meat.

\section{Results and Discussion}

\section{Feeding}

Each farmer generally have Muscovy ducks around 8 weeks old, while adult Muscovy ducks are only owned at most 1 to 2 ducks per farmer. Muscovy ducks which are raised traditionally (semi-intensive) by people in six sub-districts are fed rice bran twice a day in the morning and afternoon, then freed around house yard and needs to be put back inside in the afternoon. Usually the rice bran combined with rice from household waste add water before fed to Muscovy duck. The results of the proximate analysis of rice bran from each farmer are on Table 1 . The quality of rice bran was given to Muscovy duck varied greatly. This condition is influenced by the purchasing power of farmer and availability of rice bran. Good quality rice bran has higher price. Based on Table 4, the farmers used rice bran with protein content of 9-11\% and crude fiber content around $11-17 \%$. When compared with national standards (SNI), the rice bran used by the farmers were considered grade 2 and grade 3 .

\section{Carcass, breast meat and thigh meat weight}

Muscovy ducks live weight in the study ranged around 913-1,085 grams for males and 836-994 grams for female Muscovy duck. Based on the interviews with the farmer, the Muscovy ducks in this study were aged 8 weeks old.

Muscovy duck carcass percentage of males and females were relatively the same but the weight percentage of breast meat was higher than the thigh meat. Tugiyanti et al. (2013) 
stated that native Indonesian Muscovy duck was given rice bran as much as $98.30 \%$ and other feed $1.70 \%$ resulted in the percentage of carcasses was $63.04 \%$

The percentage resulted of this study were lower than the results obtained by Farhat et al. (1997), which is 70\% for Muscovy duck aged 11 weeks. Male Muscovy ducks have higher breast and thigh meat percentage than female Muscovy duck. It is according to Triyantini et al. (1997), the weight percentage of Muscovy duck breast was higher than the weight of the thigh (26.21\% vs. $23.86 \%)$.

In addition, the breast meat was higher than thigh meat $(15.07 \%$ vs. $13.97 \%)$ for Muscovy duck age 12 Sunday. Schavioneet al. (2007) stated that Muscovy duck which is intensively raised produce male breast meat weight percentage higher than the female Muscovy ducks aged 64 days (21.27\% vs. 20.88\%). Ogah (2009) stated that Muscovy duck males have larger body size and is heavier than the female Muscovy duck. As a food source of meat it is better to use a male Muscovy ducks in accordance with Yakubu (2011), in which the male Muscovy ducks are sold to generate income and the female Muscovy ducks are for breeding. The percentage of carcass weight, breast weights and thigh weight were higher in male Muscovy duck than that in the females because male had body weight, body length, body height greater than female (Ogah, 2009).

The variability in growth rate and body weight between male and female of the species is described as sexual dimorphism. Sexual dimorphism in growth performance of male age

Table 1. Nutritional content of rice bran on Muscovy duck farms

\begin{tabular}{lcccccc}
\hline Samples & $\begin{array}{c}\text { Moisture } \\
(\%)^{1)}\end{array}$ & Ash (\%) & $\begin{array}{c}\text { Crude } \\
\text { protein } \\
(\%)^{1)}\end{array}$ & $\begin{array}{c}\text { Ether } \\
\text { extract } \\
(\%)^{1)}\end{array}$ & $\begin{array}{c}\text { Crude } \\
\text { fiber } \\
(\%)^{1)}\end{array}$ & $\begin{array}{c}\text { Gross energy } \\
(\mathrm{kcal} / \mathrm{kg})^{2)}\end{array}$ \\
\hline Farmer 1 & 10.39 & 9.11 & 10.05 & 8.3 & 13 & 2949 \\
Farmer 2 & 11.05 & 8.0 & 9.72 & 7.7 & 11 & 2922 \\
Farmer 3 & 11.23 & 8.05 & 9.5 & 7.21 & 13 & 3004 \\
Farmer 4 & 10.76 & 9.05 & 9.9 & 8.01 & 12.9 & 2503 \\
Farmer 5 & 10.09 & 10 & 11 & 7.8 & 17 & 2901 \\
Farmer 6 & 10.65 & 9 & 9.95 & 7.5 & 13.4 & 2877 \\
\hline Mean \pm SD & $10.69 \pm$ & $8.87 \pm$ & $10.02 \pm$ & $7.75 \pm$ & $13.38 \pm$ & $2859.33 \pm$ \\
& 0.42 & 0.75 & 0.52 & 0.38 & 1.96 & 179.95 \\
\hline
\end{tabular}

Analysis result were obtained from ${ }^{1)}$ Lab..PAU IPB dan ${ }^{2)}$ Lab..ITPFapet IPB

Table 2. Carcass performance of male $(n=6)$ and female $(n=6)$ muscovy ducks

\begin{tabular}{lcccc}
\hline \multicolumn{1}{c}{ Variables } & \multicolumn{1}{c}{ Male } & \multicolumn{2}{c}{ Female } \\
& gram & $\%$ & $888.8 \pm 60.48$ & $\%$ \\
\hline Body Weight & $987.1 \pm 56.27$ & & $528.3 \pm 47.89$ & 62.8 \\
$\begin{array}{l}\text { Carcass Weight } \\
\text { Breast Meat }\end{array}$ & $622.1 \pm 74.78$ & 65.8 & $83.3 \pm 7.25$ & 15.7 \\
$\begin{array}{l}\text { Weight } \\
\text { Thigh Meat }\end{array}$ & $128.1 \pm 33.16$ & 20.6 & & 10.7 \\
Weight & $84.6 \pm 6.37$ & 13.6 & $57 \pm 8.73$ & \\
\hline
\end{tabular}

$\mathrm{n}=$ the number of Muscovy duck samples 
8 weeks is greater in value than female (Etuk, 2006). Male Muscovy duck have the ability to consume higher feed, and produced in increased body weight and feed conversion ration more male than female (Suwarta, 2013).

The percentage of carcass weight, breast weights and thigh weight were higher in male Muscovy duck than females in this study because male Muscovy duck have body weight, body length and body height greater than female (Ogah, 2009). Sexual dimorphism in growth performance of male age 8 weeks have greater value than that of the female (Etuk, 2006). The variability in growth rate and body weight between male and female of the species is described as sexual dimorphism (Raji et al, 2009). Male Muscovy duck has the ability to consume more feed and resulted in higher body weight gain and feed conversion higher than that of the female (Suwarta, 2013).

\section{Fat, cholesterol, and fatty acid content of muscovy duck meat}

Muscovy ducks raised traditionally local farm in Bogor City were fed with low nutritional content and high fiber content feed. High crude fiber content in the feed was derived from used rice bran. Aside from the feed given by the farmer, Muscovy duck also got feed when freed in backyard that could not be detected during the study. According to Setioko (1997), reared duck at backyard had various nutritional content of the crop, the feed material mainly rice, snails, insects, leaves, and also other unknown materials. If Muscovy duck were backyard they will possible most likely fed leaves, insects and other household waste (such as vegetable waste), etc. Fat, cholesterol and fatty acid content of Muscovy duck meat raised traditionally can be seen on Table 3 and the fatty acid profile on tables 4 and 5 , and T-test of average fatty acid in breast and thigh on Table 6. The information is expected to increase the demand of duck meat as a food source.
The content of fat and cholesterol of Muscovy duck breast meat varied greatly because the study results were influenced by the source of feed ingredients that were fed each day. Breast meat has lower fat content $(P<0.05)$ and higher cholesterol content $(P<0.05)$ than thigh meat in accordance with Triyantini et al. (1997) the fat content of breast meat was $0.5 \%$ and the thigh meat was $1.72 \%$ in a Muscovy duck aged 12 weeks old obtained from the traditional market in Karawang Area, West Java. Damayanti (2006) stated that cholesterol content in breast meat lower than thigh meat. Woloszym et al. (2006), reported that cholesterol in breast meat Muscovy duck lower than Pekin duck and crossbreed. The nutritional feed ingredient was manly factor influenced nutritional meat content as fat, cholesterol, and fatty acid of meat beside age, genetic, and habit of Muscovy duck. Older ducks generally have higher fat content (Tiyantini et al, 1997; Damayanti, 2006, Woloszym et al., 2006; Krimpen et al., 2011; Baeza, 2006). Thigh meat had a higher fat content $(P<0.05)$ than breast meat because it has a high red meat fiber compared to breast meat with white fibers. Meat which mostly consists of red fibers has a lower protein content and higher fat content than the meat that is composed of mostly white fibers (Soeparno, 2005). Besides, thigh meat has a higher activity than the breast meat which requires high energy.

The fatty acid profile of breast meat and thigh meat varied in this study from six local farmers (Table 4 and 5) because of different quality and quantity of rice bran and other materials that Muscovy ducks consumed while in the backyard. The profile of fatty acid showed that SFA was lower than MUFA and PUFA in breast or thigh meat. The highest MUFA compared to SFA and PUFA were similar to study by Baeza (2006) and Aronal et al. (2012). 
Table 3. Fat and cholesterol content of male Muscovy Duck $(n=6)$ breast and thigh meat

\begin{tabular}{|c|c|c|c|c|c|c|}
\hline \multirow{2}{*}{$\begin{array}{l}\text { Sample } \\
\text { Number }\end{array}$} & \multicolumn{3}{|c|}{ Breast meat } & \multicolumn{3}{|c|}{ Thigh meat } \\
\hline & $\begin{array}{l}\text { Moisture } \\
(\%)\end{array}$ & $\begin{array}{l}\text { Fat } \\
\text { (\%) }\end{array}$ & $\begin{array}{c}\text { Cholesterol } \\
\text { (\% of fat) }\end{array}$ & $\begin{array}{l}\text { Moisture } \\
\text { (\%) }\end{array}$ & $\begin{array}{l}\text { Fat } \\
(\%)\end{array}$ & $\begin{array}{l}\text { Cholesterol } \\
\text { (\% of fat ) }\end{array}$ \\
\hline 1 & 72.19 & 1.50 & 9.84 & 72.65 & 3.57 & 42.23 \\
\hline 2 & 71.35 & 1.25 & 13.05 & 72.30 & 2.83 & 36.37 \\
\hline 3 & 76.56 & 2.18 & 6.11 & 72.49 & 5.29 & 17.64 \\
\hline 4 & 74.37 & 1.74 & 9.07 & 73.89 & 3.97 & 21.18 \\
\hline 5 & 75.22 & 2.32 & 9.50 & 70.23 & 4.25 & 22.05 \\
\hline 6 & 70.45 & 3.67 & 7.84 & 71.83 & 4.43 & 14.30 \\
\hline Mean \pm & $73.36 \pm$ & $2.11^{\mathrm{a}} \pm$ & $9.24^{b} \pm$ & $72.23 \pm$ & $4.06^{b} \pm$ & $25.63^{\mathrm{a}} \pm$ \\
\hline$s d$ & 2.39 & 0.86 & 2.31 & 2.18 & 0.83 & 11.10 \\
\hline
\end{tabular}

Supercrip different in colum showed significant $(\mathrm{P}<0.05)$ (Lipid breast meat vs thigh meat), cholesterol breast meat versus thigh meat.

PUFA content in breast and thigh meat is not different from Aronal et al. (2012). The ratio of SFA/UFA is from $0.52 \pm 0.06$ to $0.58 \pm 0.06$. The fatty acid content in Muscovy duck meat with high palmitic acid and stearic acid is SFA, oleic acid is MUFA, and linoleic acid is PUFA, similar to that of Aronal et al (2012) and Schiavone et al. (2017). Palmitic acid and oleic acid are not different across breast and thigh meat but linoleic acid is higher $(P<0.05)$ than thigh meat. Aronal et al. (2012) stated $\omega 3$ fatty higher in breast meat compared to thigh meat in wild duck and Pekin duck but not Muscovy duck. The average $\omega 6$ fatty acid is not significant but the average $\omega 3$ fat in breast meat is significantly higher $(P<0.05)$ than that of thigh meat

The average ratio $\omega 6: \omega 3$ fatty acid was significantly different $(P<0.05)$ from $11.34 \pm 5.08$ (breast meat) to $23.25 \pm 22.06$ (thigh meat). Furthermore, $\omega 3$ fatty acids have an important role for health (Simopoulus, 1991). Generally, meat has lower content of $\omega 3$ fatty acid including linolenic acid, DHA and EPA, therefore it must be improved through high $\omega 3$ fatty acids supplement in feedstuff (Schiavoneet al., 2007). Schiavone et al. (2007) reported that Muscovy duck with and without $5 \%$ microalga in the diet can produced $0.74-2.12 \%$ DHA and 0.08 to $0.12 \%$ EPA. The results of study in Muscovy duck with reared traditional system showed that $\omega 3$ fatty acids as DHA and EPA content Muscovy duck meat was lower because there were high $\omega 3$ fatty acid source fed to Muscovy duck. The concentration of DHA was not significant but EPA is significantly different $(P<0.05)$ in the breast meat than that in thigh meat despite higher fat content in thigh meat. Body requires a balance between $\omega 6: \omega 3$ fatty acid. The ratio of $\omega 6: \omega 3$ fatty acid in breast meat ranged from 8.94 to 31.64 , while in thigh meat is around $6.50-24.14$. The average ratio of $\omega 6: \omega 3$ in breast meat significant $(P<0.05)$ lower than thigh meat. The ratio of $\omega 6: \omega 3$ according Aronal et al. (2012) was 7.48 in the breast meat and 2.0 in the thigh meat. Rice bran as feed ingredient was fed Muscovy duck contains high fat but has high crude fiber content that can decrease the absorption of dietary fat. Such as linoleic acid content in rice bran oil is $34.4 \%$ and the $\alpha$-linolenic acid content is $2.2 \%$ (Sayre et al., 1990). It was the reason of lower linoleic and $\alpha$-linolenic acid this study. Furthermore, the profile of fatty acids in different parts of the breast and thigh is due to the difference in the percentage of red meat fibers and white meat fibers. White meat fibers (pork) generally contain a percentage of phospholipids and PUFA inferior to red meat fibers (meat of ruminants) (Wood, et al., 2003). The fatty acid profile is also influenced by the 
fat content of meat, meat tenderness (tenderness), and meat juiciness (Wood et al., 2003). According Krejici-treuet al. (2010) some plant oils affect the fatty acid composition of breast meat and thigh meat broiler.

Table 4. Fatty acid profile in breast meat of male Muscovy ducks from local farm

\begin{tabular}{|c|c|c|c|c|c|c|c|}
\hline \multirow[t]{2}{*}{ Variables } & \multicolumn{6}{|c|}{$\begin{array}{c}\text { Breast Meat Muscovy Duck } \\
\text { (number ofsamples from } 6 \text { farm) }\end{array}$} & \multirow[t]{2}{*}{ Mean $\pm s d$} \\
\hline & 1 & 2 & 3 & 4 & 5 & 6 & \\
\hline Fat (\%) & 1.5 & 1.25 & 2.18 & 1.74 & 2.32 & 3.67 & $2.11 \pm 0.86$ \\
\hline \multicolumn{8}{|l|}{ Fatty acid : (\% fat) } \\
\hline Caprilic acid C8:0 & nd & 0.04 & 0.02 & 0.02 & 0.04 & 0.03 & $0.03 \pm 0.01$ \\
\hline Capric acid, C10:0 & 0.02 & 0.02 & 0.03 & nd & nd & nd & $0.02 \pm 0.01$ \\
\hline Lauric acidC12:0 & 0.51 & 0.28 & 0.54 & 0.33 & 0.08 & 0.17 & $0.32 \pm 0.18$ \\
\hline Myristic acid C14:0 & 0.53 & 0.45 & 0.91 & 0.63 & 0.42 & 0.54 & $0.58 \pm 0.18$ \\
\hline Pentadecanoic acid C15:0 & 0.05 & 0.04 & 0.06 & 0.05 & 0.04 & 0.04 & $0.05 \pm 0.01$ \\
\hline Heptadecanoic acid C17:0 & 0.08 & 0.08 & 0.12 & 0.1 & 0.08 & 0.08 & $0.09 \pm 0.02$ \\
\hline Palmitic acid C16:0 & 12.72 & 12.13 & 19.31 & 16.34 & 13.3 & 16.41 & $15.04 \pm 2.78$ \\
\hline Stearic acid C18:0 & 7.53 & 6.97 & 6.74 & 5.82 & 4.99 & 5.52 & $6.26 \pm 0.97$ \\
\hline Arachidic acid C20:0 & 0.19 & 0.18 & 0.19 & 0.21 & 0.2 & 0.18 & $0.19 \pm 0.01$ \\
\hline Behenic acid C22:0 & 0.17 & 0.16 & 0.09 & 0.1 & 0.09 & 0.07 & $0.11 \pm 0.04$ \\
\hline Myristolic acid C14:1 & 0.02 & 0.02 & 0.04 & 0.03 & 0.02 & 0.02 & $0.03 \pm 0.01$ \\
\hline Palmitoleic acidC16:1 & 0.78 & 0.66 & 1.56 & 1.14 & 0.87 & 1.09 & $1.0 \pm 0.32$ \\
\hline Oleic acidC18:1n9c & 18.78 & 19.69 & 29.8 & 28.02 & 23.44 & 30.11 & $24.97 \pm 5.05$ \\
\hline Elaidic acidC18:1n9t & 0.16 & 0.13 & 0.24 & 0.16 & 0.13 & 0.12 & $0.16 \pm 0.04$ \\
\hline Cis-11-Eicosenoic acid C20:1 & 0.2 & 0.2 & 0.29 & 0.32 & 0.29 & 0.35 & $0.28 \pm 0.06$ \\
\hline Nervonic acid C24:1 & 0.05 & 0.05 & 0.03 & 0.03 & 0.03 & 0.02 & $0.04 \pm 0.01$ \\
\hline Linoleic acidC18:2n6c & 6.99 & 9.4 & 7.64 & 9.21 & 9.46 & 10.73 & $8.91 \pm 1.36$ \\
\hline $\nu$-linolenic acid C18:3n6 & 0.02 & 0.02 & 0.04 & 0.03 & 0.02 & 0.03 & $0.03 \pm 0.01$ \\
\hline Linolenic acid C18:3n3 & 0.36 & 0.33 & 0.51 & 0.37 & 0.26 & 0.31 & $0.36 \pm 0.08$ \\
\hline $\begin{array}{l}\text { Cis-11,14-Eicosedienoic acid } \\
\text { C20:2 }\end{array}$ & 0.1 & 0.11 & 0.14 & 0.13 & 0.13 & 0.12 & $0.12 \pm 0.01$ \\
\hline $\begin{array}{l}\text { Cis-8,11,14-Eicosetrienoic acid } \\
\text { C20:3n6 }\end{array}$ & 0.44 & 0.37 & 0.19 & 0.17 & 0.13 & 0.11 & $0.24 \pm 0.14$ \\
\hline Arachidonic acid C20:4n6 & 5.23 & 4.87 & 1.57 & 1.54 & 1.45 & 0.96 & $2.60 \pm 1.91$ \\
\hline $\begin{array}{l}\text { Cis-5,8,11,14,17- } \\
\text { Eicosapentaenoic acid C20:5n3 } \\
\text { (EPA) }\end{array}$ & 0.28 & 0.26 & 0.1 & 0.09 & 0.03 & 0.05 & $0.14 \pm 0.11$ \\
\hline $\begin{array}{l}\text { Cis- } 4,7,10,13,16,19- \\
\text { Docosahexaenoic acid C22:6n3 } \\
\text { (DHA) }\end{array}$ & 1.31 & 0.97 & 0.38 & 0.3 & 0.19 & 0.13 & $0.5 \pm 0.48$ \\
\hline SFA & 21.8 & 20.35 & 28.01 & 23.6 & 19.24 & 23.04 & $22.7 \pm 3.08$ \\
\hline MUFA & 19.99 & 20.75 & 31.96 & 29.7 & 24.78 & 31.71 & $26.5 \pm 5.40$ \\
\hline PUFA & 14.73 & 16.33 & 10.57 & 11.84 & 11.67 & 12.44 & $12.9 \pm 2.16$ \\
\hline SFA/UFA & 0.63 & 0.55 & 0.66 & 0.57 & 0.53 & 0.52 & $0.58 \pm 0.06$ \\
\hline Fatty acid total & 56.5 & 57.4 & 70.53 & 65.16 & 55.69 & 67.21 & $62.1 \pm 6.34$ \\
\hline$\omega 6$ & 12.68 & 14.66 & 9.44 & 10.95 & 11.06 & 11.83 & $11.77 \pm 3.42$ \\
\hline$\omega 3$ & 18.94 & 19.82 & 30.04 & 28.18 & 23.57 & 30.23 & $25.13 \pm 5.10$ \\
\hline$\omega 6 / \omega 3$ & 6.50 & 9.40 & 9.54 & 14.41 & 23.04 & 24.14 & $11.34 \pm 5.08$ \\
\hline
\end{tabular}

*) Fat content of meat analysis result were obtained from The IPB Integrated Lab.

SFA (saturated fatty acid), MUFA (monounsaturated fatty acid), PUFA (polyunsaturated fatty acid), nd= not detected 
Table 5. Fatty acid profile in thigh meat of male Muscovy ducks from local farm

\begin{tabular}{|c|c|c|c|c|c|c|c|}
\hline \multirow[t]{2}{*}{ Variables } & \multicolumn{6}{|c|}{$\begin{array}{l}\text { Thigh Meat Muscovy Duck } \\
\text { (number of samples from } 6 \text { farm) }\end{array}$} & \multirow[t]{2}{*}{ Mean $\pm s d$} \\
\hline & 1 & 2 & 3 & 4 & 5 & 6 & \\
\hline Fat (\%) & 3.57 & 2.83 & 3.57 & 2.83 & 4.25 & 4.43 & $3.58 \pm 0.68$ \\
\hline \multicolumn{8}{|l|}{ Fatty acid : (\% fat) } \\
\hline Caprilic acid C8:0 & nd & nd & nd & 0.04 & nd & nd & \\
\hline Capric acid, C10:0 & nd & 0.04 & nd & nd & nd & nd & \\
\hline Lauric acidC12:0 & 0.06 & 1.35 & 0.11 & 0.16 & 0.07 & 0.11 & $0.31 \pm 0.51$ \\
\hline Myristic acid C14:0 & 0.46 & 1.07 & 0.59 & 0.57 & 0.54 & 0.52 & $0.63 \pm 0.22$ \\
\hline Pentadecanoic acid C15:0 & 0.04 & 0.03 & 0.04 & 0.05 & 0.05 & 0.05 & $0.04 \pm 0.01$ \\
\hline Palmitic acid C16:0 & 14.31 & 17.16 & 17.38 & 17.47 & 16.64 & 16.78 & $16.62 \pm 1.18$ \\
\hline Stearic acid C18:0 & 5.27 & 6.15 & 5.8 & 5.66 & 4.92 & 5.56 & $5.56 \pm 0.43$ \\
\hline Heptadecanoic acid C17:0 & 0.09 & 0.06 & 0.08 & 0.09 & 0.11 & 0.09 & $0.09 \pm 0.02$ \\
\hline Arachidic acid C20:0 & 0.2 & 0.12 & 0.21 & 0.18 & 0.19 & 0.22 & $0.19 \pm 0.04$ \\
\hline Behenic acid C22:0 & 0.06 & 0.06 & 0.05 & 0.06 & 0.06 & 0.06 & $0.06 \pm 0.00$ \\
\hline Myristolic acid C14:1 & nd & 0.05 & 0.03 & 0.03 & 0.02 & nd & $0.03 \pm 0.01$ \\
\hline Palmitoleic acidC16:1 & 0.76 & 1.53 & 1.36 & 1.34 & 1.21 & 1.01 & $1.20 \pm 0.28$ \\
\hline Elaidic acidC18:1n9t & 0.16 & 0.14 & 0.16 & 0.18 & 0.19 & 0.2 & $0.17 \pm 0.02$ \\
\hline Oleic acidC18:1n9c & 26.81 & 30.97 & 32.24 & 31.33 & 28.01 & 32.33 & $30.28 \pm 2.32$ \\
\hline Cis-11-Eicosenoic acid C20:1 & 0.35 & 0.35 & 0.39 & 0.38 & 0.29 & 0.46 & $0.37 \pm 0.06$ \\
\hline Nervonic acid C24:1 & 0.02 & 0.03 & nd & 0.02 & nd & nd & $0.02 \pm 0.01$ \\
\hline Linoleic acidC18:2n6c & 13.45 & 5.17 & 12.29 & 13.55 & 13.48 & 13.93 & $11.98 \pm 3.38$ \\
\hline$\gamma$-linolenic acid C18:3n6 & 0.03 & nd & nd & 0.03 & nd & 0.03 & $0.03 \pm 0$ \\
\hline Linolenic acid C18:3n3 & 0.33 & 0.37 & 0.35 & 0.35 & 0.39 & 0.35 & $0.36 \pm 0.02$ \\
\hline $\begin{array}{l}\text { Cis-11,14-Eicosedienoic acid } \\
\text { C20:2 }\end{array}$ & 0.16 & 0.11 & 0.15 & 0.22 & 0.13 & 0.17 & $0.16 \pm 0.04$ \\
\hline $\begin{array}{l}\text { Cis-8,11,14-Eicosetrienoic } \\
\text { acid C20:3n6 }\end{array}$ & nd & 0.14 & nd & 0.14 & nd & nd & $0.14 \pm 0$ \\
\hline Arachidonic acid C20:4n6 & 1.39 & 1.75 & 0.86 & 1.16 & 0.97 & 0.95 & $1.18 \pm 0.34$ \\
\hline Cis-5,8,11,14,17- & nd & nd & nd & 0.08 & 0.06 & 0.05 & $0.06 \pm 0.02$ \\
\hline $\begin{array}{l}\text { Eicosapentaenoic } \\
\text { acidC20:5n3 (EPA) }\end{array}$ & & & & & & & \\
\hline $\begin{array}{l}\text { Cis-4,7,10,13,16,19- } \\
\text { Docosahexaenoic acid } \\
\text { C22:6n3(DHA) }\end{array}$ & 0.14 & 0.42 & 0.08 & 0.09 & 0.11 & 0.08 & $0.15 \pm 0.13$ \\
\hline SFA & 20.49 & 26.04 & 24.26 & 24.28 & 22.58 & 23.39 & $23.49 \pm 1.87$ \\
\hline MUFA & 28.08 & 33.04 & 34.18 & 33.26 & 29.72 & 34.00 & $32.05 \pm 2.53$ \\
\hline PUFA & 15.5 & 7.96 & 13.73 & 15.62 & 15.14 & 15.56 & $13.92 \pm 3.0$ \\
\hline SFA/UFA & 0.47 & 0.64 & 0.51 & 0.50 & 0.50 & 0.47 & $0.52 \pm 0.06$ \\
\hline Fatty acid total & 64.09 & 67.08 & 72.19 & 73.17 & 67.43 & 72.95 & $69.49 \pm 3.80$ \\
\hline$\omega 6$ & 14.87 & 7.06 & 13.15 & 14.88 & 14.45 & 14.91 & $13.33 \pm 3.72$ \\
\hline$\omega 3$ & 0.47 & 0.79 & 0.43 & 0.52 & 0.56 & 0.48 & $0.57 \pm 0.17$ \\
\hline$\omega 6 / \omega 3$ & 31.64 & 8.94 & 30.58 & 28.62 & 25.80 & 31.06 & $23.25 \pm 22.06$ \\
\hline
\end{tabular}

*) Fat content of meat analysis results were obtained from The IPB Integrated Lab.

SFA (saturated fatty acid), MUFA (monounsaturated fatty acid), PUFA (polyunsaturated fatty acid), nd= not detected 
Table 6. T-Test average of fatty acid content in breast meat versus thigh meat Muscovy Duck

\begin{tabular}{|c|c|c|c|}
\hline Variables & $\begin{array}{l}\text { Breast meat } \\
\text { Mean } \pm s d\end{array}$ & $\begin{array}{l}\text { Thigh Meat } \\
\text { Mean } \pm \text { sd }\end{array}$ & $\begin{array}{l}\text { T-Test } \\
\mathrm{P}=0.05\end{array}$ \\
\hline Fat (\%) & $2.11 \pm 0.86$ & $3.58 \pm 0.68$ & $\mathrm{~S}$ \\
\hline \multicolumn{4}{|l|}{ Fatty acid : (\% fat) } \\
\hline Caprilic acid C8:0 & $0.03 \pm 0.01$ & & - \\
\hline Capric acid, C10:0 & $0.02 \pm 0.01$ & & - \\
\hline Lauric acidC12:0 & $0.32 \pm 0.18$ & $0.31 \pm 0.51$ & NS \\
\hline Myristic acid C14:0 & $0.58 \pm 0.18$ & $0.63 \pm 0.22$ & NS \\
\hline Pentadecanoic acid C15:0 & $0.05 \pm 0.01$ & $0.04 \pm 0.01$ & NS \\
\hline Palmitic acid C16:0 & $15.04 \pm 2.78$ & $16.62 \pm 1.18$ & NS \\
\hline Stearic acid C18:0 & $6.26 \pm 0.97$ & $5.56 \pm 0.43$ & NS \\
\hline Arachidic acid C20:0 & $0.19 \pm 0.01$ & $0.19 \pm 0.04$ & NS \\
\hline Behenic acid C22:0 & $0.11 \pm 0.04$ & $0.06 \pm 0.00$ & S \\
\hline Myristolic acid C14:1 & $0.03 \pm 0.01$ & $0.03 \pm 0.01$ & NS \\
\hline Palmitoleic acidC16:1 & $1.0 \pm 0.32$ & $1.20 \pm 0.28$ & NS \\
\hline Elaidic acidC18:1n9t & $0.16 \pm 0.04$ & $0.17 \pm 0.02$ & NS \\
\hline Cis-11-Eicosenoic acid C20:1 & $0.28 \pm 0.06$ & $0.37 \pm 0.06$ & S \\
\hline Nervonic acid C24:1 & $0.04 \pm 0.01$ & $0.02 \pm 0.01$ & $S$ \\
\hline Linoleic acidC18:2n6c & $8.91 \pm 1.36$ & $11.98 \pm 3.38$ & NS \\
\hline$\gamma$-linolenic acid C18:3n6 & $0.03 \pm 0.01$ & $0.03 \pm 0$ & NS \\
\hline Linolenic acid C18:3n3 & $0.36 \pm 0.08$ & $0.36 \pm 0.02$ & NS \\
\hline Cis-11,14-Eicosedienoic acid C20:2 & $0.12 \pm 0.01$ & $0.16 \pm 0.04$ & NS \\
\hline Cis-8,11,14-Eicosetrienoic acid C20:3n6 & $0.24 \pm 0.14$ & $0.14 \pm 0$ & $\mathrm{~s}$ \\
\hline Arachidonic acid C20:4n6 & $2.60 \pm 1.91$ & $1.18 \pm 0.34$ & NS \\
\hline $\begin{array}{l}\text { Cis-5,8,11,14,17-Eicosapentaenoic } \\
\text { acidC20:5n3 (EPA) }\end{array}$ & $0.14 \pm 0.11$ & $0.06 \pm 0.02$ & S \\
\hline $\begin{array}{l}\text { Cis-4,7,10,13,16,19-Docosahexaenoic } \\
\text { acid C22:6n3 (DHA) }\end{array}$ & $0.5 \pm 0.48$ & $0.15 \pm 0.13$ & NS \\
\hline SFA & $22.7 \pm 3.08$ & $23.49 \pm 1.87$ & NS \\
\hline MUFA & $26.5 \pm 5.40$ & $32.05 \pm 2.53$ & NS \\
\hline PUFA & $12.9 \pm 2.16$ & $13.92 \pm 3.0$ & NS \\
\hline SFA/UFA & $0.58 \pm 0.06$ & $0.52 \pm 0.06$ & NS \\
\hline Fatty acid total & $62.1 \pm 6.34$ & $69.49 \pm 3.80$ & $\mathrm{~S}$ \\
\hline$\omega 6$ & $11.77 \pm 3.42$ & $13.33 \pm 3.72$ & NS \\
\hline$\omega 3$ & $25.13 \pm 5.10$ & $0.57 \pm 0.17$ & $\mathrm{~S}$ \\
\hline$\omega 6 / \omega 3$ & $11.34 \pm 5.08$ & $23.25 \pm 22.06$ & S \\
\hline
\end{tabular}

$\mathrm{S}=$ significant, NS=not significant

\section{Conclusions}

Muscovy duck that were kept traditionally and provided with rice bran as the main feed had various amount of fat, cholesterol and fatty acid contents in breast meat and thigh meat.
Breast meat had higher $\omega 3$ fatty acid EPA than thigh meat but similar DHA. The study had $\omega$ 6: $\omega 3$ ratio ranged from 6.50 to 24.14 in breast meat and 8.94 to 31.64 in thigh meat. Breast meat had lower concentration of cholesterol than that of thigh meat 


\section{References}

Ali,M, Sukirno, MH Tamzil and M Ichsan. 2014. Meat traits of Muscovy duck fed on phytonutrition meal. International Journal of Poultry Science 13(4): 204-207

Aronal AP, Huda N, Ahmad R. 2012. Amino acid and fatty acid profiles of Peking and Muscovy duck meat. International Journal of Poultry Science. 11(3):229-236.

Badan Standarisasi Nasional. 1996. Dedak Padi/ Bahan Baku Pakan. SNI.01-3178-1996/Rev.92SNI. 1996. Jakarta

Baeza, E. 2006. Effect of genotype, age and nutrition on intramuscular lipids and meat quality. Symposium COA/INRA Scientific Cooperation in Agricultural. Tainan (Taiwan,R.O.C)

Damayanti, AP. 2006. Kandungan protein, lemak daging dan kulit itik, Muscovy duck dan mandalung umur 8 minggu. Journal Agroland (The Agricultural Sciences Journal) 13 (3) : 313317.

El-Deek, A Ahmed, MO Barakat, YA Attia, and AS ElSebeay. 1997. Effect of feeding Muscovy ducklings different protein sources: performance, $\infty-3$ fatty acids content, and acceptability of their tissues. Journal of the American Oil Chemists' Society 74: 999-1009.

Etuk, IF, GS Ojewola and SF Abasiekong. 2006. Performnace of muscovy duck under three management systems in South Eastern Nigeria. International Journal of Poultry Science 5(5) : 474-476

Farhat, A, L Normand, ER Chavez, SP Touchburn and PC Lague. 1997. Performance and carcass characteristics of peking and muscovy duck fed diets based on food wastes. [https://www.mcgill.ca/animal/files/animal/97r3 $\underline{0 . p d f}$.

Krauss, RM, RH Eckel, B Howard, UJ Appel, SR Daniels, RJ Deckelbaum, JW Erdman, P KrisEtherton. A Statement for healthcare professionals from the nutrition Commitee of the American health Association. Jornal of Nutrition. $131: 132-146$

Ogah DM. 2009. Analysis of morphological traits of geographically separated population of indigenous muscovy duck (Cairina moschata). International Journal of Poultry Science. 8(2): 179-182.
Raji, AO, JU Igwebuike and MT Usman. 2009. Zoometrical body measurements and their relation with live weight in nmatured local muscovy in Borno State Nigeria. Journal Agricultural and Biological Science 4(3) : 58-62

Schiavone, A, R Chiarini, M Marzoni, A Castillo, S Tassone and I Romboli.2007. Breast meat traits of Muscovy Ducks fed on a microalga (Crypthecodinium cohnii) meal supplemented diet. British Poultry Science 48(5) : 573-579

Schiavone, A, M Marzoni, A. Castillo, J.Nery and I. Romboli. 2010. Dietary lipid sources and vitamin E affect fatty acid composition or lipid stability of breast meat from Muscovy duck. Canadian Journal of Animal Science 90 (3) : 371-378

Setioko, AR. 1997. Prospek dan kendala peternakan itik gembala di Indonesia. Prosiding Seminar Nasional Peternakan dan Veteriner. Balai Penelitian Ternak, Ciawi.

Siri-Tarino, PW, S Chiu, N Bergeron, and RM Krauss. 2015. Saturated Fats versus polyunsaturated fats versus carbohydrates for cardiovascular desease prevention and treatment. Annual Review of Nutrition 35 : 517-543

Soeparno. 2005. Ilmu dan Teknologi Daging. Gajah Mada University Press.Yogyakarta.

Suwarta, FX. 2013. Evaluasi kinerja itik manila jantan dan betina pada pemberian ransum dengan aras protein yang berbeda. Jurnal AgriSains 4(6) : 1-9

Triyantini, Abubakar, IAK Bintang, dan T Antawidjaja. 1997. Studi komparatif preferensi Mutu dan Gizi beberapa jenis daging unggas. Jurnal Ilmu Ternak dan Veteriner (Indonesian Journal of Animal Veterinary Sciences) (2(3):157-161

Tugiyanti, E, T Yuwanta, Zuprizal and Rusman. 2013. Inproving performance, meat quality and muscle microstructure of native Indonesia Muscovy duck through feed protein and metabolizable energy. International Journal of Poultry Science 12 (1) : 653-659

Woloszyn, J, J Ksiazkiewicz, T Skrabka-Blotnicka, G haraf, J Biernat and T Kisiel. 2006. Comparison of amino acid and fatty acid composition of duck breast muscles from five floks. Archives Tierzucht, Dummerstorf 49 (2) : 194-204

Yakubu A. 2011. Discriminant analysis of sexual dimorphism inmorphological traits of African Muscovy ducks. Archvos de Zootecnia. 60: 11151123. 